\title{
Models of Bankruptcy Procedures in European Union
}

\author{
Pawel Dec \\ Institute of Corporate Finance and Investment \\ Warsaw School of Economics \\ Institute of Organization and Management in Industry ORGMASZ, Poland \\ E-mail: paweldec@gmail.com \\ Piotr Masiukiewicz \\ Institute of Organization and Management in Industry ORGMASZ, Poland \\ E-mail: piotr.masiukiewicz@wp.pl
}

Received: Nov. 7, 2016 Accepted: Nov. 21, 2016 Published: Dec. 4, 2016

doi:10.5296/bmh.v4i2.10275 URL: http://dx.doi.org/10.5296/bmh.v4i2.10275

\begin{abstract}
This paper focuses on the analysis of comparative models bankruptcy in selected EU countries and the evaluation of the effectiveness of the insolvency proceedings. These models are quite similar in the countries concerned; also they give the opportunity to the many variants of the bankruptcy procedure. The main thesis of the article is - so far developed and applied models of bankruptcy are still insufficient and need to be improved and reorientation to a greater extent, particularly concerning the taking into account of weak signals from the business environment. The authors analyzed the relevant theories of the firm and its reference to bankruptcy, presented various models of insolvency procedures in selected EU member states, analyzed the so-called European Company for bankruptcy. Complementing the paper detailed research on the effectiveness of insolvency proceedings in many countries. Included in the text of the conclusions show the shortage of both in theory and in practice, a comprehensive solution to the problem of insolvency proceedings.
\end{abstract}

Keywords: Bankruptcy, A second chance, Insolvency procedure, The efficiency of bankruptcy 


\section{Introduction}

Bankruptcy of enterprises for some means of catharsis economy and creating space in the market for the best, for others, bankruptcy is a social cost, loss of jobs and the stigma of failure-which was marked entrepreneur. Today we can talk about the paradigm of the primacy of the repair process (recovery) of the bankruptcy. Due to the many important concerns about the functioning of the institution of bankruptcy, can be prepare several research questions primarily:

- Whether there is significant improvement in effectiveness of insolvency proceedings?

- Whether the arbitration law (that is, transfer of registration and bankruptcy of enterprises in the country with more favorable procedures) is gaining in importance?

- Whether it is necessary full unification of bankruptcy rules in the EU?

- Whether it is reasonable to repair the paradigm of the primacy of the company over its bankruptcy?

For business practice it is important to bankruptcy courts extensively analyzed the causes of the bankruptcy of the company and have the opportunity to use different models of bankruptcy proceedings depending on the specific situation of the company.

This article focuses on the analysis of comparative models bankruptcy in selected EU countries and the evaluation of the effectiveness of the insolvency proceedings. These models are quite similar in the countries concerned; also they give the opportunity to many other variants of the bankruptcy procedure. The main thesis of the article is that now developed and applied models of bankruptcy are still insufficient and need to be improved and reorientation to a greater extent, particularly concerning the taking into account of weak signals from the business environment. In order to solve this particular problem of the research we were used, and used, among other things analysis of desk research, comparative analysis and correlation analysis.

The authors first will review the theory of bankruptcy, then make analysis of the selected model of bankruptcy procedures in the European Union Then attention will be focused on the European company and a matter of bankruptcy concerning them. Finally will be carried out in-depth research on indicators of the recovery and the number of corporate bankruptcies in European countries and, finally, at the end of the article the emphasis on the most important conclusions.

\section{Theories of the Company and Bankruptcy}

Few theories of company can be found a reference to the problems of bankruptcies and repair processes. They are (Dec, 2014; Pieńkowska, 2005):

- $\quad$ institutional theories - scale bankruptcy is determined by the quality of institutional infrastructure, e.g., Veblen, Commous, Mitchel, Clark, Galbraith 
managerial theories-avoiding bankruptcy provided the mission and goals-e.g., Baumol, Drucker, Williamson, (Williamson, 1998)

- biological theories - bankruptcy as part of the life cycle of the company, the search for the determinants of survival of the company. e.g., Hannan, Freeman

behavioral theory-survival as the goal of the company's activities, avoiding bankruptcy and restructuring optimal under the circumstances, e.g., Cyert, March, Simon, (Simon, 1988)

- $\quad$ economics of an industrial enterprise - search model of survival, e.g., Jovanovic, Ericson, Pakes

- $\quad$ theory of value for the shareholders (maximize shareholder value ensures the survival of the company in the long term, e.g., Rappaport, Marshall, Copeland, Slyvotzky (Rapaport, 1999)

According to the authors of the theory of behavioral therapy it is important today, in the context of the experience of the subprime crisis.

A number of references to the effects of bankruptcies can be found in evolutionary theory of the company. The elements of this theory are called. Routine; the company is the result of cooperation between a set of routines (technical, marketing, investment, et al.). Changes set of routines cause changes in boundaries of the enterprise market; some are developing other bankrupt. (Noga, 2009, p. 179), you can temporarily keep weak companies, but in the long term evolution, and so they will be eliminated from the market (the work of Winter, Nelson, Teece, Dosi, Mangolte and Kwaśnicki). Why some company remain alive while others go bankrupt, why the economy runs the selection of companies-widely shows the ecological theory. The basis here is the concept of survival ability of enterprises, it is assumed that natural goal is survival. Experience serve institutional and prevention limiting bankruptcy. This theory assumes that the company creates the conditions for the coexistence of competitors in the ecosystem in which we all can survive. At the same time the so-called. process demography is treated as a natural and healthy for the economy, although sometimes costly to society; Here, however, the lack of a broader analysis of the social costs of bankruptcy and insolvency, e.g., research Hannan, Freeman, Hirshleifer, Carroll and Moore. (Noga, 2009, p. 197).

As a result of cross-cutting and complex research and analysis was formed positive and normative theory of bankruptcy. A characteristic feature of the theory of positive is to identify and analyze basic dependencies that exist between the phenomenon of bankruptcy and other fundamental economic categories. The latter include, among others, economic growth with its dynamic, demand, supply, business cycle, unemployment and inflation. In turn, the normative theory of bankruptcy concerns shaping the rules necessary to rationally regulate the phenomenon of corporate bankruptcy. According to Schwartz (2005) bankruptcy of the company it is considered as a way of solving the problem of meeting the creditors of an insolvent company. The bankruptcy of the economic operator may be a function of the economic crisis or financial or both crises simultaneously. The economic crisis occurs when a 
company does not receive sufficient revenues from the sale of their goods or services to cover the cost of doing business. That company then has a negative economic value. In turn, the company is in financial difficulty when generated profits from their activities do not cover the cost of debt service of the company. Rising debt and appearing in connection with the insolvency of the company confronts its management question about the sense continue to operate. Important is thus whether the company has the ability to repay its debt in the future. It is assumed that from a social point of view, the most advantageous situation occurs when a company struggling with economic crises is liquidated, while those with financial problems continue its business activities.

At the risk of bankruptcy and bankruptcy you can also look through the prism of a variety of management theory - that bring the company into crisis. (Dec, 2014) The most famous management concept relating to the mechanisms of the crisis in the company include: the concept of development of the organization through the crisis L. E. Greiner, the concept of competition M. Porter, the concept of management of the resource G. Hamel and Prahalad C. and the theory of value migration Slywotzky (1996). The competition policy pursued by the antitrust authorities and competition known and applied a failing firm doctrine also called failing firm defense. This means that apart from the competition, protection may also apply to other values; For example, jobs, preserve strategic assets. This allows the antitrust authority declare a concentration ( $M \& A$ ) under certain conditions admissible. The rules in this area, however, are a bit different in the EU and the US.

Important significance is the theory of prediction of bankruptcy E. Altman. The author emphasizes the "sometimes substantial direct costs incurred by failing debtor related to external legal services, accounting, consulting as well as internal legal costs." (Altman \& Hitchkiss, 2006, p. 48) The cost of the experts can be a significant burden; For example, fees paid to advisers with the bankruptcy of Enron are likely to exceed $\$ 1$ billion. In this context, it is used comparative analysis of the total costs of the bankruptcy or restructuring of repair - to take appropriate decisions. For many years, the European Commission promotes "second chance program" for entrepreneurs. "Second chance" in a broad sense, both taking by entrepreneurs for the second time activities after the bankruptcy of the previous company as well as sanitation and restructuring in distress - in the frames of the rehabilitation proceedings. (Masiukiewicz \& Nowak, 2012) EU regulations and institutional arrangements are neither popularized nor sufficiently implemented - as shown by the reports of the World Bank Doing Report. European Commission's approach to bankruptcy cases can be considered revolutionary; Indeed legal bankruptcy should be a last resort; if exhausted road help entrepreneurs. But despite the bankruptcy of the entrepreneur should-with the support of various institutions to have a second chance - a chance to re-operate.

Basic instruments identified by the Commission include the following documents:

1) Communication from the Commission to the Council, the European Parliament, the European Economic and Social Committee and the Committee of the Regions "Overcoming the stigma of failure in business - for a second chance, Brussels, 2007

2) Community guidelines on State aid for rescuing and restructuring firms in difficulty 
(EC, 2016)

The European Commission believes that a more supportive environment for businesses at risk may prevent failure. Highlighting the problem of the negative effects of business failure and its negative events would help make the best of human creativity in Europe, boost entrepreneurship and promote innovation and job creation (EC, 2007). Mączyńska notes that in the framework of the theory of the company, or more broadly in the science of management does not have a separate theory of bankruptcy, explaining the mechanisms of survival, repair or bankrupt companies. (Mączyńska, 2009) She shows the development of the theory of gradually positive and normative theory in business bankruptcies, and the same time a process of permeation of these theories. (Schwartz, 2004) It seems necessary to create a theoretical foundation, a condition for the construction of modern early warning systems from bankruptcy, restructuring models repair business, models, bankruptcy procedures and infrastructure to support these activities. This applies to support for the bankruptcy courts and the entrepreneurs themselves. (Masiukiewicz, 2016)

\section{Models of Bankruptcy Procedures in the European Union}

Legal models bankruptcy in the EU countries are similar. The table below presents a comparative analysis of the main features of these models for the countries: Germany, France, the United Kingdom and Poland (table 1).

The most important differences models include, among others:

- The scope of application of the moratorium on repayment of debts of the bankrupt,

- $\quad$ Conditions repeal of bankruptcy proceedings and resume operations,

- $\quad$ Preference to the priority of claims (creditors privileged)

- $\quad$ Cancellation of the institution of bankruptcy proceedings with the lack of financial resources. 
Table 1. Models of insolvency proceedings in selected EU countries

\begin{tabular}{|c|c|c|c|}
\hline Germany & France & Great Britain & Poland \\
\hline \multicolumn{4}{|c|}{ 1. Paths of bankruptcy proceedings } \\
\hline $\begin{array}{l}\text { a/ bankruptcy court - } \\
\text { ordinary proceedings } \\
\text { b/ bankruptcy court - } \\
\text { proceedings planned }\end{array}$ & $\begin{array}{l}\text { a/ Bankruptcy collective } \\
\text { b/ continuation of } \\
\text { business - plan for } \\
\text { protection and recovery } \\
\text { plan } \\
\text { c/ liquidation of the } \\
\text { company by the court }\end{array}$ & $\begin{array}{l}\text { a/ arrangement in } \\
\text { bankruptcy } \\
\text { b/ voluntary liquidation } \\
\text { c/ compulsory liquidation }\end{array}$ & $\begin{array}{l}\text { a/ arrangement in } \\
\text { bankruptcy-the } \\
\text { continuation of business } \\
\text { activity } \\
\text { a/ bankruptcy liquidation } \\
\text { c/ suspension of } \\
\text { operations due to lack of } \\
\text { funds for bankruptcy }\end{array}$ \\
\hline \multicolumn{4}{|c|}{ 2. A moratorium of repayment of debts by the bankrupt } \\
\hline $\begin{array}{l}\text { a/ prohibition of } \\
\text { execution }\end{array}$ & $\begin{array}{l}\text { a/ non-execution } \\
b / \text { the interruption of } \\
\text { statutory interest or } \\
\text { contractual }\end{array}$ & $\begin{array}{l}\text { a/ moratorium of } \\
\text { repayment of debts in } \\
\text { bankruptcy } \\
\text { b/ warrant of debt }\end{array}$ & $\begin{array}{l}\text { a/ prohibition of } \\
\text { execution of the statutory } \\
\text { exceptions }\end{array}$ \\
\hline \multicolumn{4}{|c|}{ 3. $\quad$ Privileged debtors } \\
\hline a/ preference laws & $\begin{array}{l}\text { a/ the privilege laws - the } \\
\text { so-called creditors useful } \\
\text { (selected) }\end{array}$ & $\begin{array}{l}\text { a/ statutory hierarchy } \\
\text { preference }\end{array}$ & $\begin{array}{l}\text { a/ statutory hierarchy } \\
\text { preference }\end{array}$ \\
\hline \multicolumn{4}{|c|}{ 4. $\quad$ Responsibility of the board / director for admission to losses causing bankruptcy } \\
\hline $\begin{array}{l}\text { a/ liability } \\
\text { b/ the responsibility of } \\
\text { the Commercial Code }\end{array}$ & $\begin{array}{l}\text { a/ an action for damages } \\
\text { for "no assets" } \\
\text { b/ ban management } \\
\text { c/ penalties }\end{array}$ & $\begin{array}{l}\text { a/ disqualification } \\
\text { manager (CEO) } \\
\text { b/ liability } \\
\text { a/ criminal liability } \\
\end{array}$ & $\begin{array}{l}\text { a/ liability } \\
\text { a/ criminal liability } \\
\text { c/ ban perform } \\
\text { management functions }\end{array}$ \\
\hline \multicolumn{4}{|c|}{ 5. The establishment of the trustee / administrator by the court } \\
\hline trustee & trustee or administrator & $\begin{array}{l}\text { a/ estate manager } \\
b / \text { trustee manager } \\
c / \text { trustee official } \\
d / \text { trustee for. lien } \\
\text { permanent }\end{array}$ & $\begin{array}{l}\text { trustee } \\
\text { or liquidator }\end{array}$ \\
\hline \multicolumn{4}{|c|}{ 6. Convening the meeting of creditors of the bankrupt company } \\
\hline $\begin{array}{l}\text { a/ the creditors' meeting } \\
\text { b/ board of creditors }\end{array}$ & $\begin{array}{l}\text { a/ the creditors' } \\
\text { committee - compulsory } \\
\text { b/ assembly of } \\
\text { bondholders } \\
\text { c/ committee of credit } \\
\text { institutions }\end{array}$ & $\begin{array}{l}\text { a/ the creditors' meeting } \\
\text { b/ committee of creditors }\end{array}$ & $\begin{array}{l}\text { a/ the creditors' meeting } \\
\text { b/ board of creditors }\end{array}$ \\
\hline \multicolumn{4}{|c|}{ 7. Judicial supervision of the insolvency proceedings } \\
\hline judge commissioner & judge commissioner & judge commissioner & judge commissioner \\
\hline \multicolumn{4}{|c|}{ 8. $\quad$ The responsibility of management / directors for failure to apply for bankruptcy } \\
\hline $\begin{array}{l}\text { Criminal responsibility: } \\
\text { a/ imprisonment up to } 3 \\
\text { years } \\
\text { b/ fine }\end{array}$ & $\begin{array}{l}\text { Criminal responsibility: } \\
\text { a/ detention } \\
\text { a/ fine }\end{array}$ & $\begin{array}{l}\text { Criminal responsibility: } \\
\text { a/ detention }\end{array}$ & $\begin{array}{l}\text { Criminal responsibility: } \\
\text { a/ detention } \\
\text { b/ fine }\end{array}$ \\
\hline
\end{tabular}

Source: own prepared on the ground of (Morawska, 2011)

In Poland the institution of discontinuance of bankruptcy proceedings with the lack of financial resources. The company will continue appears in the register of companies. This solution is discussion; in such cases, costs should cover the state treasury and remove the company from the register. 
In many countries of Central and Eastern Europe bankruptcy procedures characterized by low efficiency. From the analysis of the World Bank's Doing Report it shows that in these countries the duration of the judicial procedure is long, high costs and recoveries for creditors minor. For example, some banks bankruptcy lasted up to 10 years. In Poland, we carried out a thorough reform of the regulations governing bankruptcies in 2015-to meet the program "second chance" in the EU. Regulations concerning the restructuring repair separated into a separate bill and introduced four tracks proceedings. The law on bankruptcy has been extensively revised - made short term decision, the bankruptcy court and the possibility of converting the bankruptcy proceedings to restructuring. This should significantly improve the Polish place in the annual rankings Doing Report in this regard.

\section{European Company and Bankruptcy}

European company is a kind of a public limited company governed by EU regulations. There are several reasons why you should take into account the activities of the legal form:

1) Simpler and cheaper doing business in various countries of the EU; you can e.g., lead to economic activities under one brand.

2) Greater mobility within the single market. The registered office of your company, you can move to another EU country without having to dissolve the company.

3) The appropriate framework for international operations. You can collaborate with colleagues from different countries and run your business without the need to establish branches.

To register a European company must reach an agreement with its employees as to how they will be involved in supervising the activities of the company. The registered office of your company can be transferred from one EU country to another.

Characteristics of a European company are as follows:

- $\quad$ Legal form: public limited company (a legal entity).

- Capital — at least 120 thousand. Euro must be divided into shares.

- $\quad$ The registered office and head office must be in the same country.

- $\quad$ Issues related to the termination, liquidation or insolvency is governed by national laws in this country.

In the event of bankruptcy against a European company used the same models as the insolvency proceedings against other companies. According to the art. 128 and 129 of the Polish Act on European Economic Interest Grouping and the European Company for criminal liability for failure to apply for a declaration of a grouping or a European company, despite the creation of conditions justifying bankruptcy, bear respectively grouping manager or board member, member of the board of directors or chief executive (CEO). The penalty for the above offense may be a fine, restriction of liberty or deprivation of liberty. (Morawska 2011) 


\section{The Effectiveness of the Insolvency Proceedings}

Business failure and bankruptcy of companies are permanently inscribed in the functioning of most national economies. Hence, an important indicator, which shows the effects of ongoing bankruptcy proceedings enterprises, is a pointer to recover committed there by the creditors of (recovery rate). Analysis of such an indicator allows you to assess whether both the then-current law, as well as the efficiency and functioning of justice contributes to increase the share of recoveries by creditors funds. Indeed, in an era of continuous development of financial markets, financial services, but also the same financial control or tax increase so it should be noticeable.

Table 2. Recovery rate in selected European countries in the years 2003-2015

\begin{tabular}{|c|c|c|c|c|c|c|c|c|c|c|c|c|c|}
\hline \multirow[b]{2}{*}{ Country } & \multicolumn{13}{|c|}{ Recovery rate (what $\%$ cents manage to get from $\$ 1$ ) } \\
\hline & 2003 & 2004 & 2005 & 2006 & 2007 & 2008 & 2009 & 2010 & 2011 & 2012 & 2013 & 2014 & 2015 \\
\hline Austria & 73,1 & 72,35 & 73,3 & 73,7 & 72,4 & 71,5 & 71,5 & 73,1 & 72,7 & 83,3 & 82,4 & 82,6 & 82,7 \\
\hline Belgium & 86 & 86,5 & 86,6 & 86,4 & 85,5 & 86,3 & 86,3 & 87,6 & 87,3 & 88,7 & 89 & 89,1 & 89,3 \\
\hline Czech Republic & 15,4 & 16,8 & 17,8 & 18,5 & 21,3 & 20,9 & 20,9 & 55,9 & 56 & 56,3 & 65 & 65,6 & 66 \\
\hline Denmark & 63,1 & 63,1 & 67,2 & 70,5 & 87 & 86,5 & 86,5 & 89,4 & 87,3 & 87,1 & 87 & 87,5 & 87,8 \\
\hline Estonia & 36,3 & 39,2 & 39 & 39,9 & 39,1 & 37,5 & 37,5 & 35,5 & 36,9 & 38,5 & 38,9 & 39,3 & 40 \\
\hline Finland & 88,3 & 88 & 89 & 89,1 & 88,2 & 87,3 & 87,3 & 89,4 & 89,1 & 89,7 & 90,2 & 90,2 & 90,1 \\
\hline France & 45,5 & 45,5 & 47,5 & 47,8 & 47,2 & 44,5 & 44,5 & 45 & 45,6 & 48,2 & 48,2 & 77,2 & 77,5 \\
\hline Grecece & 44,5 & 44,7 & 45,9 & 46,3 & 44,8 & 44,2 & 44,2 & 43,2 & 41,8 & 40,9 & 34 & 34,3 & 34,9 \\
\hline Spain & 73,5 & 73,2 & 74,1 & 73,8 & 72,8 & 67,6 & 67,6 & 70,5 & 75,6 & 76,5 & 72,3 & 71,3 & 71,2 \\
\hline Netherlands & 87,8 & 88,2 & 88,4 & 88,2 & 87,1 & 83,2 & 83,2 & 82,5 & 88 & 89,2 & 89,5 & 88,9 & 88,9 \\
\hline Ireland & 87,7 & 87,9 & 88 & 87,9 & 87,1 & 86,6 & 86,6 & 87,4 & 86,9 & 87,5 & 87,6 & 87,7 & 87,7 \\
\hline Luxemburg & .. & .. & .. & 41,6 & 41,6 & 41,7 & 41,7 & 43,7 & 43,5 & 43,5 & 43,5 & 44 & 43,8 \\
\hline Germany & 83,6 & 83,6 & 81,3 & 81,5 & 81,9 & 80,5 & 80,5 & 81,9 & 82,9 & 78,4 & 83,2 & 83,4 & 83,7 \\
\hline Norway & 94,4 & 87,6 & 91,1 & 91,1 & 90,7 & 89 & 89 & 90,9 & 90,6 & 90,8 & 91,3 & 92,3 & 92,5 \\
\hline Poland & 31,4 & 32,4 & 32,1 & 33,8 & 33,7 & 34,1 & 34,1 & 35,8 & 31,5 & 54,5 & 54,8 & 57 & 58,3 \\
\hline Portugal & 73,2 & 73,2 & 74,7 & 75 & 74 & 69,4 & 69,4 & 72,6 & 70,9 & 74,6 & 71,6 & 72,2 & 73,4 \\
\hline Slovakia & 39,8 & 39,6 & 38,6 & 48,1 & 45,2 & 45,9 & 45,9 & 55,3 & 54,3 & 53,6 & 54,1 & 54,4 & 54,7 \\
\hline Slovenia & 41,6 & 42,4 & 44 & 44,9 & 46,6 & 45,5 & 45,5 & 50,9 & 51,1 & 49,8 & 50,1 & 50,1 & 88,2 \\
\hline Switzerland & 45,5 & 45,9 & 46 & 46,2 & 46,2 & 45,9 & 45,9 & 46,6 & 46,6 & 46,6 & 46,6 & 46,6 & 46,6 \\
\hline Sweden & 81 & 72,3 & 74,9 & 75,7 & 74,7 & 75,1 & 75,1 & 77,3 & 75,8 & 74,7 & 75,5 & 76,1 & 76,6 \\
\hline Hungary & 38,8 & 37,9 & 35,7 & 39,7 & 38,4 & 38,4 & 38,4 & 37,9 & 39,2 & 38,8 & 38,3 & 40,2 & 41,7 \\
\hline Great Britain & 85,6 & 85,8 & 85,3 & 85,2 & 84,6 & 84,2 & 84,2 & 88,6 & 88,6 & 88,6 & 88,6 & 88,6 & 88,6 \\
\hline Italy & 34,9 & 63,2 & 63,6 & 62,5 & 61,8 & 56,6 & 56,6 & 58 & 61,1 & 63,4 & 62,7 & 62,8 & 63,1 \\
\hline
\end{tabular}

Source: http://data.worldbank.org/, 12.10.2016.

Comparing the size of the recovery rate (Table 7) it can be stated that in most of the countries, its size increased. Only in Greece, Spain, Norway and Sweden has been a reverse situation, 
but considering the case even Norway ratio still remained at a very high level and amounted in 2015 almost 93\%. However, in Spain and Sweden, it amounted to $71.2 \%$ and $54.7 \%$, in contrast to Greece, where it reached only less than 35\%. Equally low rates achieved in 2015, countries such as Estonia (40\%), Luxembourg (44\%), Hungary (42\%). Poland in this category is below average, because the indicator was in 2015 just over 58\%. However, comparing it to 2003, it is visible almost doubled its growth. In addition to Norway, the biggest indicator of the recovery in 2015 reached countries such as Finland (90\%), the United Kingdom, the Netherlands, Belgium (approx. 89\%), Slovenia, Ireland (approx. 88\%).

In addition, it was carried out to analyze the relationships between the numbers of bankrupt enterprises indicators of recovery. These data are shown in the following table. 
Table 3. Comparative analysis of the number of corporate bankruptcies in selected countries an indicator of the recovery of funds involved in the company for the years 2008 to 2013

\begin{tabular}{|c|c|c|c|c|c|c|c|}
\hline \multirow{2}{*}{ Country } & \multirow[b]{2}{*}{ Indicator } & \multicolumn{6}{|l|}{ Year } \\
\hline & & 2008 & 2009 & 2010 & 2011 & 2012 & 2013 \\
\hline \multirow{2}{*}{ Austria } & number of bankrupt businesses & 23813 & 25487 & 29551 & 30399 & 31504 & 31821 \\
\hline & recovery rate & 71,5 & 71,5 & 73,1 & 72,7 & 83,3 & 82,4 \\
\hline \multirow{2}{*}{ Belgium } & number of bankrupt businesses & 17549 & 19242 & 17936 & 12082 & 13449 & 11700 \\
\hline & recovery rate & 86,3 & 86,3 & 87,6 & 87,3 & 88,7 & 89 \\
\hline \multirow{2}{*}{$\begin{array}{l}\text { Czech } \\
\text { Republic }\end{array}$} & number of bankrupt businesses & 68910 & 76631 & 86820 & 90426 & 118658 & 96503 \\
\hline & recovery rate & 20,9 & 20,9 & 55,9 & 56 & 56,3 & 65 \\
\hline \multirow{2}{*}{ Denmark } & number of bankrupt businesses & & 26305 & 23671 & 22987 & 24661 &.. \\
\hline & recovery rate & 86,5 & 86,5 & 89,4 & 87,3 & 87,1 & 87 \\
\hline \multirow{2}{*}{ Estonia } & number of bankrupt businesses & 9853 & 10621 & 7065 & 6064 & 6225 &.. \\
\hline & recovery rate & 37,5 & 37,5 & 35,5 & 36,9 & 38,5 & 38,9 \\
\hline \multirow{2}{*}{ Finland } & number of bankrupt businesses & 21846 & 23808 & 24470 & & 17800 & 18165 \\
\hline & recovery rate & 87,3 & 87,3 & 89,4 & 89,1 & 89,7 & 90,2 \\
\hline \multirow{2}{*}{ France } & number of bankrupt businesses & 206556 & 212502 & 202274 & 193351 & 171433 & 168030 \\
\hline & recovery rate & 44,5 & 44,5 & 45 & 45,6 & 48,2 & 48,2 \\
\hline \multirow{2}{*}{ Spain } & number of bankrupt businesses & 310598 & 305446 & 280762 & 289980 & 294961 & 280668 \\
\hline & recovery rate & 67,6 & 67,6 & 70,5 & 75,6 & 76,5 & 72,3 \\
\hline \multirow{2}{*}{ Netherlands } & number of bankrupt businesses & 58700 & 48153 & 63431 & 77597 & 91885 & 87538 \\
\hline & recovery rate & 83,2 & 83,2 & 82,5 & 88 & 89,2 & 89,5 \\
\hline \multirow{2}{*}{ Ireland } & number of bankrupt businesses & 19530 & 24511 & 16116 & 18076 & 10493 & 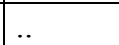 \\
\hline & recovery rate & 86,6 & 86,6 & 87,4 & 86,9 & 87,5 & 87,6 \\
\hline \multirow{2}{*}{ Luxemburg } & number of bankrupt businesses & 2006 & 1962 & 2062 & 2164 & 2133 & 2272 \\
\hline & recovery rate & 41,7 & 41,7 & 43,7 & 43,5 & 43,5 & 43,5 \\
\hline \multirow{2}{*}{ Germany } & number of bankrupt businesses & & 261297 & 253123 & 255206 & 254009 & 237509 \\
\hline & recovery rate & 80,5 & 80,5 & 81,9 & 82,9 & 78,4 & 83,2 \\
\hline \multirow{2}{*}{ Norway } & number of bankrupt businesses & 18570 & 17099 & 16180 & 11824 & 13563 & 12737 \\
\hline & recovery rate & 89 & 89 & 90,9 & 90,6 & 90,8 & 91,3 \\
\hline \multirow{2}{*}{ Poland } & number of bankrupt businesses & 165216 & 206614 & 207003 & 224670 & 244054 &.. \\
\hline & recovery rate & 34,1 & 34,1 & 35,8 & 31,5 & 54,5 & 54,8 \\
\hline \multirow{2}{*}{ Portugal } & number of bankrupt businesses & 148198 & 149578 & 137331 & 138518 & 147299 & .. \\
\hline & recovery rate & 69,4 & 69,4 & 72,6 & 70,9 & 74,6 & 71,6 \\
\hline \multirow{2}{*}{ Slovakia } & number of bankrupt businesses & 39358 & 38351 & 26882 & 59767 & 49468 & 39866 \\
\hline & recovery rate & 45,9 & 45,9 & 55,3 & 54,3 & 53,6 & 54,1 \\
\hline \multirow{2}{*}{ Slovenia } & number of bankrupt businesses & 7522 & 8890 & 10507 & 10353 & 11615 & 10338 \\
\hline & recovery rate & 45,5 & 45,5 & 50,9 & 51,1 & 49,8 & 50,1 \\
\hline \multirow{2}{*}{ Sweden } & number of bankrupt businesses & 37430 & 40295 & 40112 & 37342 & 53723 & 48641 \\
\hline & recovery rate & 75,1 & 75,1 & 77,3 & 75,8 & 74,7 & 75,5 \\
\hline \multirow{2}{*}{ Hungary } & number of bankrupt businesses & 62193 & 53950 & 62408 & 77958 & 87042 & 95604 \\
\hline & recovery rate & 38,4 & 38,4 & 37,9 & 39,2 & 38,8 & 38,3 \\
\hline \multirow{2}{*}{$\begin{array}{l}\text { Great } \\
\text { Britain }\end{array}$} & number of bankrupt businesses & 253760 & 298510 & 224360 & 204750 & 222555 & 213770 \\
\hline & recovery rate & 84,2 & 84,2 & 88,6 & 88,6 & 88,6 & 88,6 \\
\hline It & number of bankrupt businesses & 283273 & 242980 & 257983 & 272778 & 320511 & 333305 \\
\hline Italy & recovery rate & 56,6 & 56,6 & 58 & 61,1 & 63,4 & 62,7 \\
\hline
\end{tabular}

Source: Own based on: http://data.worldbank.org/, 12.10.2016

In the case of Austria correlation between the changes in the number of bankrupt enterprises a recovery ratio in $2008-2013$ is 0.75 , so it can be said that with the increase in the number of corporate bankruptcies following simultaneous increase in recovery rate. Similarly, in the 
case of the Czech Republic correlation between the change in the number of bankrupt enterprises the recovery ratio in $2008-2013$ is 0.74 , and also it can be said that with the increase in the number of corporate bankruptcies following simultaneous increase in recovery rate. However, in the case of Belgium, the correlation between the change in the number of bankrupt enterprises and the recovery ratio in 2008-2013 is -0.75 , which indicates that the decline in the number of corporate bankruptcies followed by a simultaneous increase in recovery rate. On the other hand, in the case of Spain, the correlation between the change in the number of bankrupt enterprises and the recovery ratio in 2008-2013 is 0.49 , so we have almost a similar situation as in Belgium. There is a decrease in the number of bankruptcies of companies and at the same time we increase the recovery rate. In the case of Germany, the correlation between the change in the number of bankrupt enterprises and the recovery ratio in 2008-2013 is -0.50 . So also we have a decrease in the number of bankrupt enterprises and the simultaneous increase in the recovery rate. However, in the case of Polish correlation between the change in the number of bankrupt enterprises and the recovery ratio in 2008-2013 is 0.61 . Therefore, a growing number of bankrupt businesses fortunately entails an increase in the recovery rate. For other European countries indicators of correlation between the number of bankrupt enterprises and the value of recovery rate in selected countries in 2008-2013 are presented in the table below.

Table 4. The values of the correlation coefficient between the number of bankrupt enterprises and the value of recovery rate in selected countries in 2008-2013

\begin{tabular}{|c|c|}
\hline Country & Correlation coefficient \\
\hline Austria & 0,7468899 \\
\hline Belgium & $-0,7467333$ \\
\hline Czech Republic & 0,7400253 \\
\hline Denmark & $-0,5703642$ \\
\hline Estonia & 0,1283754 \\
\hline Finland & $-0,5953303$ \\
\hline France & $-0,98883$ \\
\hline Spain & $-0,4942532$ \\
\hline Netherlands & 0,9254942 \\
\hline Ireland & $-0,8799182$ \\
\hline Luxemburg & 0,754596 \\
\hline Germany & $-0,5039488$ \\
\hline Norway & $-0,7861276$ \\
\hline Poland & 0,6061614 \\
\hline Portugal & $-0,2755602$ \\
\hline Slowakia & 0,153588 \\
\hline Slovenia & 0,8382744 \\
\hline Sweden & $-0,3918083$ \\
\hline Hungary & 0,3435748 \\
\hline Great Britain & $-0,8903926$ \\
\hline Italy & 0,8157891 \\
\hline & \\
\hline
\end{tabular}

Source: Own study. 
It shows even that in the case of the UK and Ireland, where he found a strong negative correlation, there is a decrease in the number of bankrupt companies with simultaneous increase in the recovery rate. In Italy and the Netherlands (positive correlation) increase in the number of bankruptcy following the increase in recovery rate. Of course, it would be advisable further examination of these indicators with regard to qualitative changes, such as even a change in the law.

\section{Conclusions}

The problem of business bankruptcies and the related matter further bankruptcy proceedings, despite the vaguely good recognition in the literature and analysis in business practice still seems to be the object of necessary changes. Moreover, according to the authors multiplicity of various approaches in different countries to these issues it makes it easy to operate both international corporations, institutions and what its controlling or supervising. That is why it is so important after all, standardize procedures and tools, both concerning the overall issues associated with corporate financial reporting, as well as the requirements and procedures of bankruptcy. According to the authors fail to resolve here the action of international institutions and the weakness of the national authorities to tardiness and excessive length of commercial courts recognize a bankruptcy case. Fast and efficient judicial decisions would allow not only the use of human resources and assets for starting new investment projects, but also curtail the temptation of making fraud in this area. The challenge in the next study should analyze the cases of successful bankruptcy proceedings, which contributed to the creation of new enterprises and the reorganization of business models.

\section{References}

Altman, E. I., \& Hotchkiss, E. (2006). Corporate Financial Distress and Bankruptcy: Predict and Avoid Bankruptcy, Analyze and Invest in Distressed Debt. New York: Wiley.

Dec, P. (2014). Niepewność funkcjonowania przedsiębiorstw: Bankructwa, restrukturyzacja, likwidacja. Warszawa: Oficyna Wydawnicza SGH.

Masiukiewicz, P., \& Nowak, M. (2012). Financial Leverage Models versus Bankruptcy Enterprises. Journal of International Scientific Publications Economy \& Business, 6(4).

Masiukiewicz, P. (2012). Rehabilitation Proceedings and Company Value. In S. Morawska (Ed.), Ekonomia $i$ prawo upadłości przedsiębiorstw. Zarządzanie przedsiębiorstwem $w$ kryzysie. Warszawa: Oficyna Wydawnicza SGH.

Masiukiewicz, P. (2016). Restructuration and Recovery of Enterprises. Break of Barriers. Theory of Management, University Zilina, No. 1.

Mączyńska, E. (2014). Bankructwa przedsiębiorstw. Wybrane aspekty ekonomiczne i prawne. Warszawa: Oficyna Wydawnicza SGH.

Mączyńska, E. (2009). Upadłość przedsiębiorstwa. Zaprzestanie działalności. In I. Lichniak (Ed.), Nauka o przedsiębiorstwie. Wybrane zagadnienia. Warszawa: Oficyna Wydawnicza $\mathrm{SGH}$. 


\section{Macrothink}

Business and Management Horizons

ISSN 2326-0297

Morawska, S. (2011). Modele postępowań upadłościowych w Polsce i wybranych krajach UE. Warszawa: Oficyna Prawa Polskiego.

Noga, A. (2009). Teorie przedsiębiorstw. Warszawa: PWE.

Pieńkowska, M. (2005). Ujęcie upadłości w teorii przedsiębiorstwa. In E. Mączyńska (Ed.), Ekonomiczne aspekty upadłości przedsiębiorstw w Polsce. Warszawa: IFGN SGH.

Rapaport, A. (1999). Wartość dla akcjonariuszy. Poradnik menedżera i inwestora. Warszawa: WIG-Press.

Schwartz, A. (2004). Normative Theory of Business Bankruptcy. Paper 32, Yale University.

Schwartz, A. (2005). A Normative Theory of Business Bankruptcy. Virginia Law Review, 91(5).

Simon, H. A. (1988). Organizations and Markets. Pittburgh: Carnegie Mellon University.

Slywotzky, A. (1996). Value Migration: How to Think Several Moves Ahead of the Competition. Boston: Harvard Business School Press.

Syp, S. (2014). Economics of failing firm doctrine. In E. Mączyńska (Ed.), Bankructwa przedsiębiorstw. Wybrane aspekty ekonomiczne i prawne. Warszawa: Oficyna Wydawnicza SGH, 2014.

Williamson, O. E. (1998). Ekonomiczne instytucje kapitalizmu. Warszawa: PWN.

\section{Copyright Disclaimer}

Copyright for this article is retained by the author(s), with first publication rights granted to the journal.

This is an open-access article distributed under the terms and conditions of the Creative Commons Attribution license (http://creativecommons.org/licenses/by/3.0/). 